\title{
Pengembangan Perangkat Pembelajaran Ikatan Kimia dengan Model Kooperatif Tipe Jigsaw untuk Meningkatkan Hasil Belajar Peserta Didik SMA
}

\author{
Marliana Muttar \\ Pendidikan Kimia, Universitas Negeri Makassar \\ Email: marlianamuttar@yahoo.co.id \\ Muhammad Danial \\ Pendidikan Kimia, Universitas Negeri Makassar \\ Email: muhammaddanial@yahoo.com \\ Sugiarti Sugiarti \\ Pendidikan Kimia, Universitas Negeri Makassar \\ Email: atisugiarti34@yahoo.co.id
}

(Diterima: 10-Januari-2021; direvisi: 11-Februari-2021; dipublikasikan: 28-Maret-2021)

\begin{abstract}
Abstrak: Penelitian ini merupakan penelitian pengembangan (research and development) yang bertujuan untuk: (1) mengetahui proses pengembangan perangkat pembelajaran ikatan kimia dengan model kooperatif tipe Jigsaw untuk meningkatkan hasil belajar peserta didik SMA, (2) mengetahui tingkat kevalidan, kepraktisan, dan keefektifan produk pengembangan perangkat pembelajaran ikatan kimia dengan kooperatif tipe Jigsaw untuk meningkatkan hasil belajar peserta didik SMA. Model pengembangan perangkat pembelajaran yang digunakan adalah model 4-D yang terdiri dari tahap pendefinisian (define), tahap perancangan (design), tahap pengembangan (develop), dan tahap penyebaran (disseminate). Perangkat pembelajaran yang dikembangkan adalah RPP, LKPD, BAPD, Media, dan THB. Setelah validasi, dilakukan uji coba perangkat pembelajaran model kooperatif tipe Jigsaw di SMAN 7 Jeneponto pada kelas X.MIA 1 dengan jumlah peserta didik sebanyak 35 orang. Hasil penelitian menunjukkan bahwa perangkat pembelajaran model kooperatif tipe Jigsaw yang dikembangkan menunjukkan kevalidan rata-rata 3,75 dengan kriteria sangat valid. Perangkat pembelajaran model kooperatif tipe Jigsaw dikatakan praktis, karena pada uji kepraktisan yang berhubungan dengan: (1) keterlaksanaan perangkat pembelajaran model kooperatif tipe Jigsaw berada pada nilai rata-rata $\mathrm{M}=1,9$ dalam kategori $(1,5 \leq \mathrm{M} \leq 2,0)$ yang artinya aspek dan kriteria yang diamati pada pelaksanaan perangkat pembelajaran model kooperatif tipe Jigsaw berada pada kategori terlaksana seluruhnya, (2) guru memberikan respon yang sangat positif terhadap perangkat pembelajaran model kooperatif tipe Jigsaw dengan persentase 92,59\%, dan (3) peserta didik memberikan respon yang sangat positif terhadap perangkat pembelajaran berbasis model kooperatif tipe Jigsaw dengan persentase 92,77\%. Perangkat pembelajaran ini dikatakan efektif karena memenuhi kriteria keefektifan, dengan hasil belajar peserta didik diperoleh rata-rata persentase $81,91 \%$ dengan ketuntasan klasikal 87,50\%, sedangkan peningkatan hasil belajar berdasarkan uji $\mathrm{N}$-gain sebesar 0,78 dengan kriteria tinggi. Dengan demikian, hasil penelitian menunjukkan bahwa produk perangkat pembelajaran yang dikembangkan termasuk valid, praktis, dan efektif.
\end{abstract}

Kata kunci: Perangkat Pembelajaran; Kooperatif Tipe Jigsaw; Hasil Belajar.

Abstract: This study is development research (research and development) which aims at examining (1) the development process of chemical bond learning devices using cooperative 
model of Jigsaw type to improve learning outcomes of senior high school students, (2) the level of validity, practicality, and effectiveness of development product of chemical bond learning devices using cooperative model of Jigsaw type to improve learning outcomes of senior high school students. The development model of learning devices employed in this study was 4.D model which consisted of defining stage, design stage, development stage, and dissemination stage. The learning devices developed in this study were RPP, LKPD, BAPD, media, and THB. The chemical bond learning devices using cooperative model of Jigsaw type was validated by two experts. After being validated, the test of cooperative model of Jigsaw type was conducted at SMAN 7 Jeneponto in class X. MIA 1 with 35 students. The results of the study reveal that the learning devices of cooperative model of Jigsaw type which had been developed indicated that the average validity was 3,75 with very valid criteria. The learning devices of cooperative model of Jigsaw type was stated as practical because the practicality test which related to (1) the implementation of learning devices of cooperative model of Jigsaw type was in average value $M=1.9$ in category $(1.5 \leq M \geq 2.0)$ which means that the aspect and criteria being observed on the implementation of learning devices of cooperative model of Jigsaw type is in implemented entirely category, (2) the teacher gave very positive response on learning devices of cooperative model of Jigsaw type with $92.07 \%$, and (3) the students gave very positive response on learning devices based on cooperative model of Jigsaw type with $92.77 \%$. The learning devices is stated as effective because it has met effective criteria with the learning outcomes obtained the average of $81.91 \%$ and classical completeness $87.50 \%$, whereas, the improvement of learning outcomes based on N-gain test was 0,78 with high criteria. Therefore, the result of the study indicates that the product of learning devices which had been developed is valid, practical, and effective.

Keywords: Learning Device; Cooperative of Jigsaw Type; Learning Outcomes.

\section{PENDAHULUAN}

Tingkat pemahaman peserta didik terhadap suatu materi pelajaran akan banyak ditentukan oleh sejauh mana terselenggaranya proses belajar mengajar dengan baik dalam kelas dan sesuai dengan fungsi dan tujuan yang diharapkan. Sehingga untuk mencapai proses belajar mengajar yang efektif dan efisien, tidak mungkin dicapai dengan metode yang bersifat "teacher centered" atau komunikasi satu arah. Model pembelajaran yang harus diterapkan adalah metode multi arah, salah satunya yaitu dengan pembelajaran kooperatif, karena pembelajaran kooperatif merupakan suatu upaya dalam perubahan pendidikan dan pembelajaran.

Ikatan Kimia menjadi salah satu materi pokok mata pelajaran kimia yang harus dipelajari oleh peserta didik SMA untuk mencapai kompetensi sikap, pengetahuan, dan keterampilan. Di dalam pokok bahasan ikatan kimia terdapat banyak informasi tentang fakta dan konsep yang merupakan pengetahuan deklaratif dan membutuhkan pembuktian melalui pengamatan. Selain itu materi ini banyak berhubungan dengan kehidupan sehari-hari, sehingga peserta didik mampu menerapkan dan mengaitkan pengetahuan yang dimiliki dengan kehidupan sehari-hari.

Berdasarkan hal diatas menjadi sebuah pertimbangan bagi seorang pendidik untuk memilih model pembelajaran dan menyediakan alat bantu mengajar yang tepat sebagai faktor penunjang proses pembelajaran di kelas. Adapun alat bantu yang dimaksud adalah perangkat pembelajaran. Perangkat pembelajaran sebagai penunjang pembelajaran berupa RPP dipilih karena berfungsi sebagai pedoman guru dalam melaksanakan proses pembelajaran. LKPD dipilih karena berfungsi sebagai sumber belajar pendukung yang dapat memberikan kesempatan kepada peserta didik untuk melakukan kegiatan penemuan secara mandiri maupun bekerja sama. Perangkat pembelajaran perlu 
diwarnai dengan model pembelajaran yang sesuai. Salah satu model pembelajaran yang kiranya cocok digunakan dalam perangkat pembelajaran di atas adalah model discovery learning.

Melalui model ini diharapkan peserta didik mampu mengembangkan kemampuan pemecahan masalah yang dihadapinya dalam pembelajaran kimia yang berkaitan dengan materi asam basa dan garam yang sedang dipelajari. Kemampuan pemecahan masalah merupakan bagian terpenting dari peserta didik yang harus dikembangkan melalui pembelajaran, dalam penelitian ini guru hanya sebagai fasilitator yang berfungsi sebagai jembatan penghubung agar peserta didik dapat memecahkan permasalahan kimia sendiri. Peserta didik akan mendapatkan kesempatan untuk menemukan dan mengembangkan ide-ide baru dalam kegiatan memecahkan permasalahan tersebut.

Secara umum ada empat langkah yang harus dilakukan peserta didik untuk memahami masalah meliputi: (1) memahami masalah, (2) merencanakan pemecahannya, (3) melaksanakan rencana, (4) memeriksa kembali prosedur dan hasil penyelesaian. Model pengembangan yang digunakan yaitu 4-D, adapun alasan dipilihnya model ini karena peneliti menganggap model inilah yang sesuai digunakan dalam mengembangkan perangkat pembelajaran yang berbasis discovery learning. Model 4D ini memiliki beberapa kelebihan dengan model-model lain diantaranya: (1) langkahlangkah pengembangannya jelas, sistematis, dan terarah sehingga menuntun setiap pengguna model ini untuk menggunakan langkah tersebut hingga proses akhir penggunaan produk yang dihasilkan; (2) hasil pengembangannya dapat mencapai apa yang diharapkan karena instrumen sudah teruji oleh ahli dan praktisi sebelum digunakan; (3) kajian pengembangan model ini mengarahkan pada produktivitas guru dengan menghasilkan produk perangkat pembelajaran yang lengkap; (4) prosedur pengembangan pembelajaran relevan dan sesuai dengan prinsip pengembangan perangkat pembelajaran kurikulum 2013. Hal ini sesuai dengan penelitian yang dilakukan oleh Luthfi, Danial, \& Wijaya (2016), menunjukkan bahwa hasil belajar peserta didik yang diberi tugas secara berkelompok dengan model pembelajaran discovery learning lebih tinggi dengan nilai rata-rata 73,80 dibandingkan dengan bekerja secara individu dengan nilai rata-rata hasil belajar 67,71. Selain itu, terdapat penelitian Nurhasanah, Kania, \& Sunendar (2018) menunjukkan bahwa penggunaan model pembelajaran discovery learning dapat meningkatkan kemampuan pemecahan masalah matematis peserta didik SMP kelas VIII dengan kategori sangat baik. Hal ini dibuktikan dengan nilai rata-rata di akhir pembelajaran sebesar 54 dari skor maksimal 80 yang pada awalnya hanya memiliki ratarata 5,44 dari skor maksimal 80 .

\section{METODE}

Penelitian ini termasuk dalam jenis penelitian Research and Development (R\&D) yang dikembangkan dengan menggunakan model pengembangan 4-D (Define, Design, Develop, Disseminate) oleh Thiagarajan, Semmel, \& Semmel (1974). Uji coba perangkat dilaksanakan di SMP Negeri 36 Makassar dengan subjek penelitian kelas VII semester ganjil tahun pelajaran 2019/2020. Instrumen penelitian yang digunakan adalah lembar validasi, lembar observasi keterlaksanaan pembelajaran, angket respon guru, angket respon peserta didik, lembar kemampuan pemecahan masalah, dan tes hasil belajar. Teknik analisis data yang digunakan yakni teknik analisis statistik deskriptif.

Data yang dianalisis adalah Analisis data kevalidan perangkat pembelajaran, analisis data kepraktisan perangkat pembelajaran, dan analisis data keefektifan perangkat pembelajaran.

\section{HASIL DAN PEMBAHASAN}
1. Proses Pengembangan Perangkat Pembelajaran Berbasis Discovery Learning


Proses pengembangan perangkat pembelajaran berbasis discovery learning ini menggunakan model 4D dari Thiagarajan yang terdiri dari empat tahap yaitu define, design, develop, dan disseminate. Tahapan yang dilakukan dimulai dari analisis awal akhir yang bertujuan untuk mengetahui dan menetapkan masalah dasar yang dihadapi dalam proses pembelajaran. Masalah mendasar dari SMP Negeri 36 Makassar yaitu rendahnya kemampuan pemecahan masalah peserta didik yang berdampak pada rendahnya hasil belajar. Kegiatan pembelajaran yang masih menggunakan model konvensional yang kurang melibatkan peserta didik dalam kegiatan pembelajaran. Hal ini mengakibatkan peserta didik tidak terbiasa mengkonstruk pengetahuan karena peserta didik hanya mendengar dan mencatat materi yang disampaikan sehingga mengakibatkan rasa bosan dan kurang bersemangat dalam proses pembelajaran. Analisis peserta didik untuk mengetahui karakteristik peserta didik yang sesuai dengan rancangan dan pengembangan perangkat pembelajaran melalui observasi, hasil yang diperoleh bahwa peserta didik di SMP Negeri 36 Makassar memiliki kemampuan heterogen yakni berkemampuan tinggi, sedang, dan rendah. Peserta didik pada umumnya memiliki gaya belajar visual yakni belajar dengan mengutamakan indera pengelihatan dimana peserta didik lebih tertarik jika divisualisasikan baik melalui gambar maupun dialami secara langsung seperti praktikum, dan diperlihatkan dengan hal-hal yang berkaitan dengan kehidupan sehari-hari.

Analisis materi, pada analisis ini diperoleh konsep-konsep utama dalam materi asam basa dan garam dan dibuat dalam suatu urutan materi hirarkis. Analisis tugas, setelah dilakukan analisis ini diperoleh bahwa tugas yang diberikan dapat memberikan pemahaman terhadap materi yang sedang dipelajari. Tugas-tugas dalam LKPD dikerjakan secara berkelompok selama pembelajaran berlangsung kemudian dilanjutkan dengan kuis atau evaluasi yang dikerjakan secara individu. Analisis tujuan pembelajaran, tahap ini terdiri atas 3 langkah yaitu (1) penyusunan tes, (2) pemilihan media yang sesuai tujuan, (3) pemilihan format, menentukan format isi perangkat pembelajaran. Untuk itu dipilih format yang sesuai dengan karakteristik dan langkahlangkah pembelajaran discovery learning tahapan selanjutnya adalah mengembangkan perangkat pembelajaran meliputi RPP, LKPD, BAPD, Media, dan THB. Tahapan terakhir adalah mengevaluasi perangkat pembelajaran melalui serangkaian proses, yaitu validasi ahli, revisi, dan uji coba perangkat sehingga dihasilkan perangkat pembelajaran yang valid, praktis, dan efektif.

\section{Kualitas Perangkat Pembelajaran} Berbasis Discovery Learning

Secara umum, hasil penelitian terhadap perangkat pembelajaran yang meliputi RPP, LKPD, BAPD, Media, dan THB dapat dilihat pada Tabel 1.

Tabel 1. Rangkuman Hasil Validasi Perangkat

\begin{tabular}{clcc}
\hline No. & \multicolumn{1}{c}{ Perangkat } & $\begin{array}{c}\text { Rata-rata Skor } \\
\text { Validasi }\end{array}$ & Kategori \\
\hline 1. & Rencana Pelaksanaan Pembelajaran (RPP) & 3,6 & Sangat Valid \\
2. & Lembar Kerja Peserta Didik (LKPD) & 3,6 & Sangat Valid \\
3. & Bahan Ajar Peserta Didik (BAPD) & 3,8 & Sangat Valid \\
4. & Media & 3,7 & Sangat Valid \\
5. & Tes Hasil Belajar (THB) & 3,8 & Sangat Valid \\
\hline \multicolumn{2}{r}{ Rata-rata Total } & 3,7 & Sangat Valid \\
\hline
\end{tabular}

Hasil analisis terhadap RPP pada memperlihatkan bahwa rata-rata penilaian validator terhadap RPP dari aspek format RPP, materi (isi) yang disajikan, bahasa, 
alokasi waktu, manfaat/kegunaan RPP, sarana dan alat bantu pembelajaran adalah 3,6 dengan kategori sangat valid karena berada pada rentang $3,5 \leq \mathrm{X} / \mathrm{Y} / \mathrm{Z} \leq 4$. Hal ini berarti bahwa RPP disusun sesuai dengan prinsip-prinsip pengembangan RPP dan seluruh komponen dalam penyusunan RPP telah tercantum sehingga RPP ini dapat diterapkan dalam kegiatan pembelajaran. Meskipun demikian ada beberapa aspek yang perlu diperhatikan agar dapat menghasilkan RPP yang lebih baik yakni ketepatan penjabaran kompetensi dasar ke indikator pencapaian kompetensi, pengembangan indikator menjadi tujuan pembelajaran, dan kesesuaian tujuan pembelajaran dengan tingkat perkembangan kognitif peserta didik. Hasil uji kelayakan terhadap perangkat pembelajaran juga dilakukan oleh Khomsiatun \& Retnawati (2015) hasil validasi RPP menunjukkan total skor adalah 495 sehingga RPP termasuk dalam kategori "valid" sehingga RPP yang dihasilkan layak digunakan setelah dilakukan perbaikan-perbaikan sesuai aturan.

Hasil analisis terhadap LKPD memperlihatkan bahwa rata-rata penilaian terhadap LKPD ditinjau dari aspek format LKPD, bahasa, isi LKPD, waktu, manfaat/kegunaan LKPD adalah 3,6 dengan kategori "sangat valid" yaitu berada pada rentang $3,5 \leq \mathrm{X} / \mathrm{Y} / \mathrm{Z} \leq 4$. Hal ini berarti bahwa LKPD ini dapat digunakan sebagai bahan ajar dalam kegiatan pembelajaran. Namun demikian berdasarkan saran dan komentar validator maka dilakukan revisi kecil untuk penyempurnaan perangkat LKPD. (1) cantumkan indikator pembelajaran pada setiap LKPD, (2) cantumkan keterangan gambar pada setiap gambar yang ditampilkan. Hasil uji kelayakan LKPD juga dilakukan oleh Hutami \& Wiyatmo (2018), berdasarkan penilaian validator LKPD yang dihasilkan termasuk dalam kategori sangat baik dengan skor rata-rata sebesar 4,4.

Hasil analisis terhadap BAPD memperlihatkan bahwa rata-rata penilaian terhadap bahan ajar peserta didik ditinjau dari aspek adalah format BAPD, bahasa, isi BAPD, dan manfaat/ kegunaan BAPD adalah 3,8 dengan kategori "sangat valid" yaitu berada pada rentang $3,5 \leq \mathrm{X} / \mathrm{Y} / \mathrm{Z} \leq 4$. Hal ini berarti bahwa BAPD telah dapat digunakan sebagai bahan ajar dalam kegiatan pembelajaran. Namun demikian berdasarkan saran dan komentar validator maka dilakukan revisi kecil untuk penyempurnaan perangkat bahan ajar peserta didik. (1) sebaiknya dicantumkan indikator pembelajaran pada setiap BAPD yang dikembangkan, (2) sebaiknya dicantumkan setiap keterangan gambar jika terdapat lebih dari satu gambar pada satu kesatuan gambar yang ditampilkan. Hasil penelitian ini sejalan dengan hasil penelitian yang dilakukan oleh Rahmawati, Mardiyana, \& Subanti (2014), diperoleh hasil validasi buku peserta didik yaitu semua komponen penilaian berada dalam kategori "sangat baik" sehingga perangkat layak digunakan.

Hasil analisis terhadap THB memperlihatkan bahwa rata-rata penilaian terhadap THB ditinjau dari aspek materi soal, konstruksi, dan bahasa adalah 3,8 dengan kategori "sangat valid" yaitu berada pada rentang $3,5 \leq \mathrm{X} / \mathrm{Y} / \mathrm{Z} \leq 4$. Namun demikian, tes hasil belajar yang disusun tetap direvisi sedikit dengan memperhatikan indikator pencapaian kompetensi dimana soal yang dibuat harus sesuai. Tes hasil belajar yang telah direvisi diujcobakan sebelum pembelajaran kimia berbasis discovery learning pada materi asam basa dan garam untuk mengetahui kemampuan awal peserta didik dan setelah proses pembelajaran berabsis discovery learning untuk mengukur kemampuan pemecahan masalah dan hasil belajar peserta didik setelah mengikuti proses pembelajaran.

Dalam proses pengembangan instrumen ini terdapat beberapa instrumen pengumpulan data yang dikembangkan melalui proses validasi. Instrumen yang dimaksud adalah lembar keterlaksanaan pembelajaran, lembar angket respon guru, lembar angket respon peserta didik, dan lembar kemampuan pemecahan masalah. Adapun rekapitulasi penilaian validator 
terhadap instrumen penelitian dapat dilihat pada Tabel 2.

Tabel 2. Rekapitulasi Hasil Validasi terhadap Instrumen Penelitian

\begin{tabular}{clcl}
\hline No. & \multicolumn{1}{c}{ Perangkat Pembelajaran } & Penilaian & Kategori \\
\hline 1. & Lembar observasi keterlaksanaan pembelajaran & 3,9 & Sangat Valid \\
\hline 2. & Lembar angket respon guru & 3,7 & Sangat Valid \\
3. & Lembar angket respon peserta didik & 3,7 & Sangat Valid \\
\hline & Rata-rata Total & 3,8 & Sangat Valid \\
\hline
\end{tabular}

Berdasarkan tabel 2, menunjukkan bahwa keseluruhan komponen lembar keterlaksanaan pembelajaran, lembar angket respon guru, lembar angket respon peserta didik, dan lembar kemampuan pemecahan masalah dinilai sangat valid yaitu berada pada rentang $3,7 \leq \mathrm{X} / \mathrm{Y} / \mathrm{Z} \leq 4$. Penilaian secara umum oleh para ahli untuk instrumen penelitian ini adalah baik dan dapat digunakan dengan sedikit revisi. Tujuan utama analisis data keterlaksanaan perangkat pembelajaran adalah untuk melihat sejauh mana tingkat keterlaksanaan perangkat dalam proses pembelajaran. Perangkat berdasarkan hasil analisis data dan observasi pengamatan tentang keterlaksanaan pembelajaran selama tiga pertemuan dapat dilihat pada Tabel 3.

Tabel 3. Hasil Analisis Pengamatan Keterlaksanaan Perangkat Pembelajaran

\begin{tabular}{clcc}
\hline No. & \multicolumn{1}{c}{ Aspek } & Penilaian & \multicolumn{1}{c}{ Kategori } \\
\hline 1. & Sintaks & 1,9 & Terlaksana Seluruhnya \\
2. & Interaksi Sosial & 1,8 & Terlaksana Seluruhnya \\
3. & Prinsip Reaksi & 1,9 & Terlaksana Seluruhnya \\
4. & Sistem Pendukung & 1,9 & Terlaksana Seluruhnya \\
\hline & Rata-rata Total & 1,9 & Terlaksana Seluruhnya \\
\hline
\end{tabular}

Berdasarkan analisis data yang ditunjukkan pada tabel 3 nilai rata-rata keterlaksanaan perangkat pembelajaran kimia berbasis discovery learning adalah 1,9 dengan kategori terlaksana seluruhnya karena berada pada rentang $1,5 \leq \mathrm{M} \leq 2,0$. Hal ini menunjukkan bahwa perangkat pembelajaran yang dikembangkan dapat digunakan dalam pembelajaran kimia di kelas khususnya untuk materi asam basa dan garam. Berdasarkan hasil penilaian pengamat dan hasil analisis persentase kesepahaman dapat disimpulkan bahwa keterlaksanaan perangkat pembelajaran kimia telah diujicobakan dan telah memenuhi kirteria praktis. Hasil analisis tersebut dapat dilihat pada Tabel 4.

Tabel 4. Hasil Analisis Respon Guru

\begin{tabular}{clcl}
\hline No. & \multicolumn{1}{c}{ Aspek } & Penilaian & Kategori \\
\hline 1. & Penilaian terhadap RPP & 95,00 & Sangat Positif \\
2. & Peniilaian terhadap LKPD & 95,00 & Sangat Positif \\
3. & Penilaian terhadap BAPD & 87,50 & Sangat Positif \\
4. & Penilaian terhadap Media & 90,00 & Sangat Positif \\
5. & Penilaian terhadap THB & 92,86 & Sangat Positif \\
\hline & Rata-rata Total & 92,07 & Sangat Positif \\
\hline
\end{tabular}


Berdasarkan hasil yang ditunjukkan pada tabel 4 rata-rata respon guru sebesar 92,07 yaitu berada pada kategori sangat positif. Hal ini berarti bahwa perangkat pembelajaran yang telah dikembangkan praktis dan dapat digunakan dalam pembelajaran kimia berbasis discovery learning. Hasil analisis respon guru terhadap RPP menunjukkan bahwa hal yang perlu diperhatikan yaitu kesesuaian antara banyaknya indikator dengan waktu yang disediakan, rincian waktu yang digunakan dalam RPP cukup untuk setiap pertemuan. Respon guru terhadap BAPD yang perlu diperhatikan yaitu materi yang ada dalam buku peserta didik lengkap, menarik tetapi masih ada beberapa bagian yang belum dipahami, gambar yang disajikan dalam buku peserta didik belum sepenuhnya membantu dalam memahami materi yang dipelajari masih diperlukan penjelasan yang lebih lengkap. Hasil analisis respon guru terhadap LKPD, yang perlu diperhatikan yaitu waktu yang dibutuhkan dalam setiap kegiatan pada LKPD terutama pada saat pengolahan data, serta kemudahan penggunaan LKPD berbasis discovery learning, terutama dalam mengubah kebiasaan peserta didik dalam belajar di kelas. Angket respon peserta didik diberikan setelah mengikuti kegiatan pembelajaran, respon peserta didik terhadap perangkat pembelajaran dibagi menjadi tiga aspek yaitu respon terhadap perangkat pembelajaran dan proses pembelajaran, respon terhadap bahan ajar peserta didik, dan respon terhadap lembar kerja peserta didik. Hasil analisis data respon peserta didik diisi oleh 32 peserta didik dan dapat dilihat pada Tabel 5.

Tabel 5. Hasil Analisis Respon Peserta Didik

\begin{tabular}{clcc}
\hline No. & \multicolumn{1}{c}{ Aspek } & Rata-rata Persentase & Keterangan \\
\hline 1. & Respon terhadap perangkat & 94,18 & Sangat Positif \\
2. & Rembelajaran dan proses pembelajaran & 92,53 & Sangat Positif \\
3. & Respon terhadap BAPD & 91,60 & Sangat Positif \\
\hline & Rata-rata Total & 92,77 & Sangat Positif \\
\hline
\end{tabular}

Respon peserta didik terhadap pelaksanaan pembelajaran berdasarkan angket yang diberikan diperoleh persentase sebesar 94,18\%, respon peserta didik terhadap bahan ajar peserta didik sebesar 92,53\% dan respon terhadap LKPD sebesar 91,60\%. Dari keseluruhan aspek yang diamati rata-rata respon positif yang diberikan oleh peserta didik adalah $92,77 \%$. Hal ini menunujukkan bahwa rata-rata peserta didik setuju terhadap pelaksanaan pembelajaran berbasis discovery learning, dan seluruh aspek yang ditanyakan dalam pelaksanaan kegiatan pembelajaran dengan menggunakan perangkat pembelajaran kimia berbasis discovery learning didapatkan respon positif yang sangat tinggi atau sangat positif. Dari persentase tersebut menunjukan bahwa kriteria perangkat pembelajaran dikatakan efektif jika respon peserta didik minimal berada pada kategori positif, sehingga perangkat pembelajaran efektif digunakan dalam kegiatan pembelajaran.

Dari analisis respon peserta didik, rata-rata peserta didik memberikan penilaian dalam skala setuju, respon peserta didik positif terhadap kegiatan pembelajaran, LKPD, BAPD berbasis discovery learning. Dengan pembelajaran berbasis discovery learning minat belajar peserta didik lebih baik, terlibat aktif dalam belajar kelompok untuk memperoleh pengetahuan, berdiskusi, bertukar ide. Saran untuk LKPD yaitu perlu penambahan ruang kosong untuk menuliskan jawaban, peserta didik menganggap ruang yang disediakan tidak cukup untuk menuliskan beberapa jawaban. Untuk BAPD diharapkan untuk didesain lebih menarik sehingga peserta didik lebih termotivasi untuk belajar masih diperlukan 
tambahan contoh soal sehingga bisa menjadi referensi bagi peserta didik dalam menyelesaikan soal-soal yang terkait.

Analisis kemampuan pemecahan masalah dilakukan dengan menggunakan instrument berupa tes soal uraian yang mengukur empat item kemampuan pemecahan masalah yaitu: (1) memahami masalah, (2) merencanakan pemecahannya,
(3) melaksanakan rencana, dan (4) memeriksa kembali prosedur dan hasil penyelesaian. Instrumen ini digunakan untuk mengukur kemampuan pemecahan masalah peserta didik secara individu setelah dilakukan proses pembelajaran menggunakan perangkat pembelajaran berbasis discovery learning. Adapun hasil yang diperoleh dapat dilihat pada Tabel 6 .

Tabel 6. Statistik Nilai Kemampuan Pemecahan Masalah Peserta Didik

\begin{tabular}{lcc}
\hline \multicolumn{1}{c}{ Variabel } & Nilai Statistik \\
& Pre-test & Post-test \\
\hline Subjek Penelitian & 32 & 32 \\
Nilai Maksimum & 33,33 & 83,89 \\
Nilai Minimum & 23,33 & 65,56 \\
Rata-rata & 27,22 & 74,50 \\
Jumlah peserta didik tuntas & 0 & 28 \\
Jumlah peserta didik tidak tuntas & 32 & 4 \\
\hline
\end{tabular}

Berdasarkan tabel 6 menunjukkan bahwa kemampuan pemecahan masalah peserta didik kelas VII SMP Negeri 36 Makassar terhadap pembelajaran kimia berbasis discovery learning pada materi asam basa dan garam diperoleh skor ratarata 74,50 dengan kategori baik. Hasil untuk masing-masing indikator yaitu untuk indikator 1 dalam tes kemampuan pemecahan masalah terdapat pada butir 1 dan 3. Pada penilaian indikator 1 disajikan permasalahan mengenai bahan dilingkungan sekitar yang kemudian peserta didik diminta untuk mengelompokkan berdasarkan konsep asam basa dan garam. Hasil analisis pada indikator 1 diperoleh nilai rata-rata untuk soal nomor 1 yaitu 10,84 dan soal nomor 2 yaitu 9,36 .

Pengkategorian hasil belajar berdasarkan kategori diperoleh distribusi frekuensi dan persentase nilai hasil belajar dapat dilihat pada Tabel 7.

Tabel 7. Distribusi Frekuensi dan Persentase Nilai Hasil Belajar Kimia

\begin{tabular}{ccccccc}
\hline \multirow{2}{*}{$\begin{array}{c}\text { Interval } \\
\text { Nilai }\end{array}$} & \multirow{2}{*}{ Predikat } & \multirow{2}{*}{ Keterangan } & \multicolumn{2}{c}{ Pre-test } & \multicolumn{2}{c}{ Post-test } \\
\cline { 4 - 7 } & & Frekuensi & Persentase & Frekuensi & Persentase \\
\hline $93-100$ & A & Sangat baik & - & - & 4 & 12,50 \\
$85-92$ & B & Baik & - & - & 15 & 46,87 \\
$75-84$ & C & Cukup & - & - & 9 & 28,12 \\
$<75$ & D & Kurang & 32 & 100 & 4 & 12,50 \\
\hline
\end{tabular}

Tabel 7, menunjukkan bahwa dari 32 peserta didik yang mengikuti tes hasil belajar sebelum dilakukan pembelajaran kimia berbasis discovery learning pada materi asam basa dan garam $100 \%$ peserta didik berada pada kategori kurang. Sedangkan setelah dilakukan proses pembelajaran menggunakan perangkat pembelajaran berbasis discovery learning terdapat $12,50 \%$ pada kategori kurang $28,12 \%$ pada kategori cukup, $46,87 \%$ pada kategori baik, dan $12,50 \%$ pada kategori sangat baik.

Apabila hasil belajar peserta didik dianalisis maka persentase ketuntasan hasil belajar dapat dilihat pada Tabel 8 . 
Muttar, Danial, Sugiarti. Pengembangan perangkat pembelajaran ....

Tabel 8. Deskripsi Ketuntasan Hasil Belajar

\begin{tabular}{ccccccc}
\hline Interval & \multirow{2}{*}{ Nilai } & \multirow{2}{*}{ Predikat } & \multirow{2}{*}{ Keterangan } & \multicolumn{2}{c}{ Pre-test } & \multicolumn{2}{c}{ Post-test } \\
\cline { 4 - 7 } & & & Frekuensi & Persentase & Frekuensi & Persentase \\
\hline $75-100$ & Tuntas & Sangat Baik & - & - & 28 & 87,50 \\
$0-74$ & Tidak & Baik & 32 & $100 \%$ & 4 & 12,50 \\
\hline
\end{tabular}

Tabel 8, menunjukkan bahwa dari 32 peserta didik yang mengikuti tes hasil belajar sebelum dilakukan pembelajaran kimia berbasis discovery learning pada materi asam basa $100 \%$ peserta didik berada pada kategori tidak tuntas. Sedangkan setelah dilakukan proses pembelajaran menggunakan perangkat pembelajaran berbasis discovery learning terdapat $87,50 \%$ peserta didik yang tuntas dan $12,50 \%$ peserta didik yang tidak tuntas. Pembelajaran dikatakan berhasil secara klasikal jika minimal $80 \%$ peserta didik mencapai nilai minimal yaitu 75 . Berdasarkan persentase penguasaan tes hasil belajar peserta didik memenuhi standar ketuntasan secara klasikal.

Analisis peningkatan hasil belajar peserta didik berdasarkan uji N-gain diperoleh sebesar 0,82 maka dapat dikatakan peningkatan hasil belajar dalam kategori tinggi setelah digunakan perangkat pembelajaran berbasis discovery learning pada proses pembelajarannya.

Tes hasil belajar diberikan kepada peserta didik untuk memperoleh informasi tentang penguasaan peserta didik terhadap materi yang telah diajarkan. Hasil belajar peserta didik kelas VII SMP Negeri 36 Makassar terhadap pembelajaran kimia berbasis discovery learning pada materi asam basa dan garam diperoleh skor ratarata 83,48 dari skor maksimal 100. Skor terendah 63,13 dan skor tertinggi 98,94 dengan rentang skor 42,31. Berdasarkan hasil analisis bahwa persentase hasil belajar peserta didik sebesar $12,59 \%$ berada pada kategori sangat baik, 46,87\% pada kategori baik, 28,12\% berada pada kategori cukup, dan $12,50 \%$ pada kategori kurang. Dari 32 peserta didik yang mengikuti tes hasil belajar, terdapat $87,50 \%$ peserta didik yang tuntas, dan $12,50 \%$ peserta didik yang tidak tuntas. Pembelajaran dikatakan berhasil secara klasikal jika minimal $80 \%$ peserta didik mencapai nilai minimal 75 .

Pada dasarnya penelitian seperti ini telah pernah dilakukan oleh peneliti sebelumnya Azzahro (2014). Dari hasil penelitian diperoleh data menunjukkan bahwa secara klasikal, peserta didik memperoleh pemahaman yang baik terhadap materi yang disajikan dengan menggunakan perangkat pembelajaran kimia berbasis discovery learning. Penelitian yang dilakukan oleh Luthfi, Danial, \& Wijaya (2016) dengan demikian, perangkat pembelajaran kimia berbasis discovery learning efektif digunakan pada pembelajaran asam basa dan garam.

\section{SIMPULAN DAN SARAN}

Berdasarkan hasil penelitian dan pembahasan, maka dapat disimpulkan bahwa pengembangan perangkat pembelajaran pada penelitian ini menggunakan model 4-D yang terdiri dari 4 tahap, yaitu pendefenisian (define), perancangan (design), pengembangan (develop), dan tahap penyebaran (dessiminate). Secara umum hasil pengembangan perangkat pembelajaran dalam penelitian ini valid, praktis dan efektif. (a) Valid, berdasarkan hasil validasi oleh ahli pada perangkat pembelajaran berupa Rencana Pelaksanaan Pembelajaran (RPP), Lembar Kegiatan Peserta Didik (LKPD), Bahan Ajar Peserta Didik (BAPD), media dan Tes Hasil Belajar (THB) dikategorikan "Sangat Valid", (b) praktis, berdasarkan hasil pengamatan oleh observer bahwa perangkat pembelajaran terlaksana Seluruhnya" pada saat uji coba, sedangkan secara keseluruhan respon guru dan peserta didik berada pada kategori "Sangat Positif" 
dan (c), efektif, kemampuan pemecahan masalah peserta didik berada pada kategori baik dan ketuntasan belajar peserta didik secara klasikal tercapai.

Berdasarkan hasil yang diperoleh dari penelitian ini, dapat dikemukakan beberapa saran yaitu pengembangan perangkat pembelajaran kimia berbasis discovery learning hendaknya dikembangkan untuk materi lain yang cocok diajarkan dengan model ini, sehingga peserta didik akan lebih termotivasi dan dapat mengkonstruksi sendiri pengetahuannya. Bagi peneliti yang berminat mengembangkan lebih lanjut penelitian ini, diharapkan untuk melihat bagaimana kondisi peserta didik dan menggunakan observer yang disesuaikan dengan banyaknya komponen yang diamati.

\section{DAFTAR RUJUKAN}

Azzahro, I. F. 2014. Pengembangan Perangkat Pembelajaran Berbasis Discovery Learning pada Sub Materi Respirasi dan Fotosintesis Kelas VII SMP. Pensa E-Jurnal: Pendidikan Sains, 2(3), 1-9.

Hanafiah, Nanang, \& Suhana, C. 2012. Konsep Strategi Pembelajaran. Bandung: Refika Aditama.

Hutami, D. P., \& Wiyatmo, Y. 2018. Pengembangan Perangkat Pembelajaran Berbasis Guided Discovery Learning untuk Meningkatkan Pemahaman Konsep dan Kemampuan Kerjasama Peserta Didik. Jurnal Pendidikan Fisika, 7(1), 18-28.

Khomsiatun, S., \& Retnawati, H. 2015. Pengembangan Perangkat Pembelajaran dengan Penemuan Terbimbing (Discovery Learning) untuk Meningkatkan Kemampuan Pemecahan Masalah. Jurnal Riset Pendidikan Matematika, 2(1), 92106.

Luthfi, A. I., Danial, M., \& Wijaya, M. 2016. Perbandingan Metode Pemberian Tugas Kerja Kelompok dan Kerja Individu pada Model
Pembelajaran Discovery Learning terhadap Hasil Belajar Peserta Didik Kelas XI MIA SMAN 1 Tondong Tallasa Kab. Pangkep (Studi pada Materi Pokok Termokimia). Jurnal Chemica, 17(1), 58-66.

Nurhasanah, D. E., Kania, N., \& Sunendar, A. 2018. Penggunaan Model Pembelajaran Discovery Learning untuk Meningkatkan Kemampuan Pemecahan Masalah pada Siswa SMP. Jurnal Didactical Mathematics, 1(1), 21-32.

Rahmawati, Y., Mardiyana, \& Subanti, S. 2014. Pengembangan Perangkat Pembelajaran Berbasis Penemuan Terbimbing (Guided Discovery) dengan Pendekatan Somatic, Auditory, Visual, Intellectual (SAVI) pada Materi Pokok Peluang Kelas IX SMP Tahun Ajaran 2013/2014. Jurnal Elektronik Pembelajaran Matematika, 2(4), 379-388.

Thiagarajan, S., Semmel, D. S., \& Semmel, M. I. $\quad$ 1974. Instructional Development for Training Teachers of Exceptional Children. Minneapolis, Minnesota: Leadership Training Institute/ Special Education, University of Minnesota. 